\title{
PERILAKU NGEBUT DAN PERSEPSI PENGENDARA SUMATERA BARAT
}

\author{
Speeding Behaviour and Driver Perception in West Sumatra
}

\author{
Purnawan \\ Jurusan Teknik Sipil \\ Fakultas Teknik, Universitas Andalas \\ Kampus Unand Limau Manih, Kec. Pauh \\ Padang, Sumatera Barat \\ purnawan@ft.unand.ac.id
}

\author{
Titi Kurniati \\ Jurusan Teknik Sipil \\ Fakultas Teknik, Universitas Andalas \\ Kampus Unand Limau Manih, Kec. Pauh \\ Padang, Sumatera Barat \\ titi@ft.unand.ac.id
}

\begin{abstract}
Speeding behavior is one of the factors that could cause traffic accidents. Speeding is generally carried out based on certain reasons. This study aims to determine speeding behavior in Padang city and the driver's perception of speeding behavior. To get speeding behavior in the field, the spot speed survey was conducted, while to find out perceptions about speeding behavior, an online survey was conducted. The results of the survey data analysis showed that drivers were speeding at peak and not peak hours; the percentage of drivers speeding up even more during the afternoon and evening. The driver was speeding due to internal factors and external factors that simultaneously supported the driver to drive the vehicle with speeding.
\end{abstract}

Key words: speed, speeding, driver perception

\begin{abstract}
Abstrak
Perilaku ngebut merupakan salah satu faktor yang dapat menimbulkan kecelakaan lalu lintas, tindakan ngebut pada umumnya dilakukan atas dasar alasan tertentu. Penelitian ini bertujuan untuk mengetahui perilaku ngebut di kota Padang, dan persepsi pengemudi atas perilaku ngebut. Untuk mendapatkan perilaku ngebut di lapangan, dilakukan survai kecepatan setempat, sedang untuk mengetahui persepsi tentang perilaku ngebut dilakukan survai online. Hasil analisa data survai menunjukkan bahwa pengemudi ngebut pada jam puncak dan tidak puncak, persentase jumlah pengemudi ngebut semakin banyak pada saat sore dan malam hari. Pengemudi ngebut disebabkan adanya faktor internal dan faktor eksternal yang secara bersamaan mendukung pengemudi mengendarai kendaraan dengan ngebut.
\end{abstract}

Kata kunci : kecepatan, ngebut, persepsi pengemudi

\section{PENDAHULUAN}

Jumlah kecelakaan lalu lintas di Indonesia cenderung meningkat dengan meningkatnya jumlah kepemilikan kendaraan. Data Korlantas pada tahun 2019 menunjukkan bahwa jumlah korban kecelakaan lalu lintas tertinggi terjadi pada masyarakat yang berusia 15-19 th, dilihat dari usia tersebut maka mereka adalah siswa SMP, SMA dan mahasiswa yang baru kuliah. Hasil penelitian Soehodho (2009) pada data tahun sebelumnya, diperoleh kesimpulan bahwa manusia adalah faktor utama (93\%) yang menjadi penyebab terjadinya kecelakaan, terlihat bahwa jumlah kecelakaan meningkat dengan pola yang sama sesuai dengan pola meningkatnya volume lalu lintas. Sedang Santosa et al (2017) menyatakan bahwa 88\% kecelakaan di Indonesia disebabkan oleh faktor manusia, jumlah ini lebih kecil dari hasil penelitian sebelumnya, namun manusia tetap merupakan faktor utama penyebab kecelakaan. Dari data makro kecelakaan di Indonesia, Yusuf et al (2017) menyatakan bahwa sepeda motor memberi kontribusi terbesar atas terjadinya kecelakaan, salah satu 
faktor yang berkontribusi tinggi terhadap terjadinya kecelakaan adalah kecepatan kendaraan dengan pengemudi yang mengendarai kendaraan dengan kecepatan tinggi. Mehmood (2007) menyatakan bahwa penyebab pengemudi mengemudi melebihi batas kecepatan didasarkan atas faktor internal dan faktor eksternal, yang termasuk didalam faktor internal meliputi persepsi resiko dari penerapan hukum, persepsi tentang pengemudi ngebut, dan tingkat kesadaran pengemudi, sedang yang termasuk didalam faktor eksternal antara lain, usia pengemudi, kinerja kendaraan yang tinggi, kondisi jalan, kondisi lalu lintas dan lingkungan, sedang Corner dkk (2007) menggunakan teori perilaku yang direncanakan (theory of planned behavior) untuk memprediksi keinginan pengemudi untuk mengendarai kendaraan melebihi batas kecepatan yang ditetapkan. Warner (2006) menyatakan bahwa tindakan mengemudi melebihi batas kecepatan yang ada didsarkan atas pendapat subyektif, kemampuan mengendalikan perilaku yang dilakukan dan norma moral dari teori perilaku yang direncanakan. Hasil yang menarik dari penelitian Moller dan Haustein (2014), mereka menemukan bahwa terdapat sikap negatif dari pengemudi muda laki-laki terhadap batas kecepatan, norma hukuman subyektif dan resiko yang akan diterima jika terjadi kecelakaan pada saat ngebut.Berdasarkan kondisi diatas, bahwa pengendara ngebut di jalan dikarenakan adanya factor internal dan faktor eksternal, untuk itu maka diperlukan penelitian tentang perilaku pengendara pada saat mengendarai kendaraan agar diperoleh factor internal dan eksternal yang mempengaruhi pengemudi ngebut.

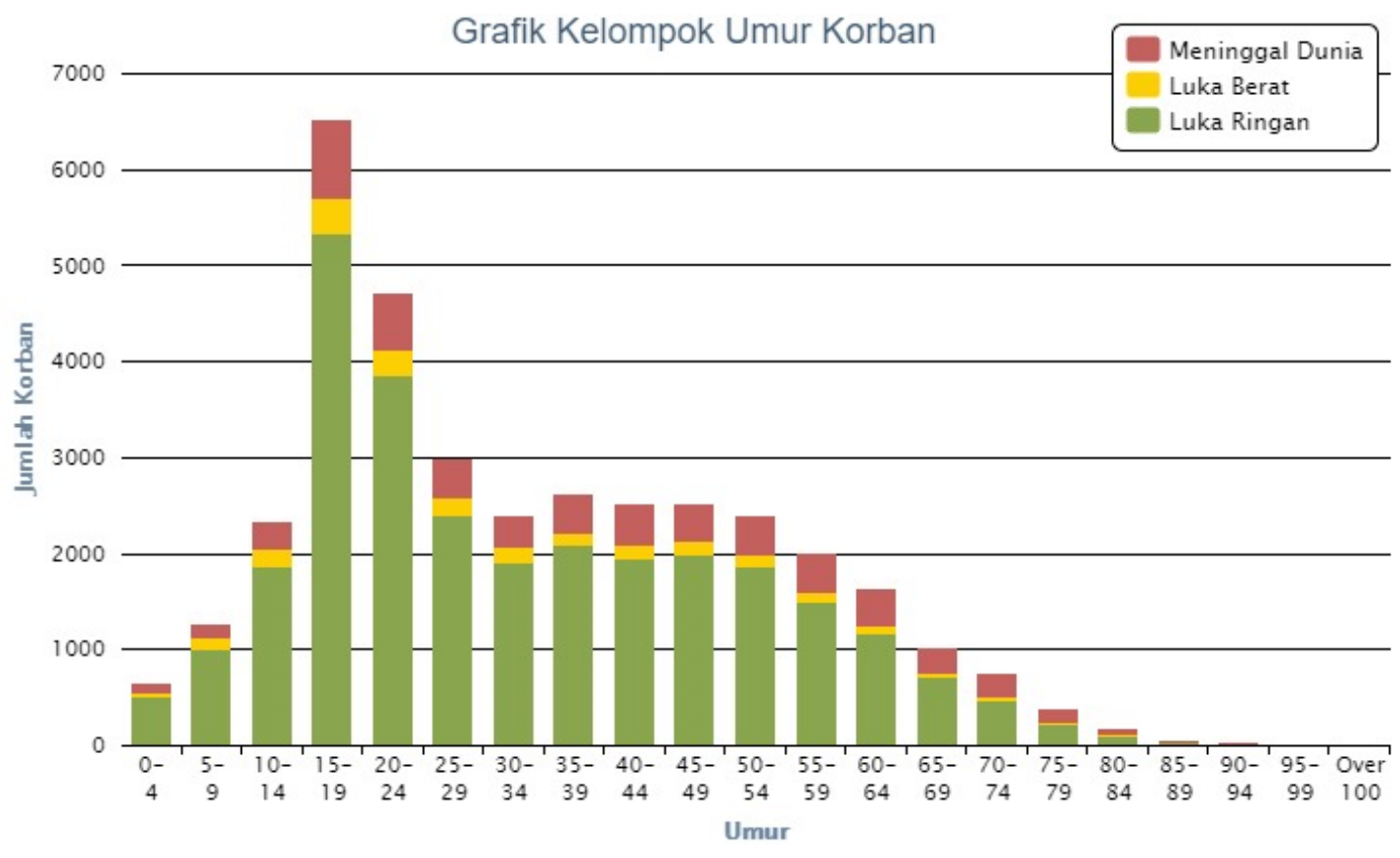

Gambar 1. Jumlah korban kecelakaan lalu lintas berdasarkan kelompok umur Sumber : Korlantas (2019)

\section{METODE PENELITIAN}

Dalam melaksanakan penelitian ini, untuk mendapatkan kasus ngebut yang dapat mewakili berbagai kondisi, maka dilakukan survai kecepatan pada jam puncak dan tidak puncak. Sedang untuk mendapatkan perilaku ngebut yang tidak dipengaruhi oleh kondisi geometric 
dan hambatan samping, maka ditetapkan jalan Adinegoro sebagai lokasi tempat survai. Lokasi survai terletak di jalan Adinegoro $3 \mathrm{~km}$ sebelum batas kota Padang, ruas jalan ini mempunyai 4 lajur terpisah dengan median, kondisi geometrik jalan ini relatif lurus dan datar dengan hambatan samping yang relatif kecil. Survai dilakukan jam puncak dan jam tidak puncak pagi, siang, sore dan malam hari, pengukuran kecepatan dilakukan dengan menggunakan speedgun. Sedang untuk mengetahui persepsi tentang ngebut dari pengemudi, maka dilakukan survai secara online terhadap 300 responden yang mayoritas adalah warga yang tinggal di Padang, pengukuran persepsi pengemudi dilakukan dengan metode Likert. Variabel yang dieksplorasi dari responden adalah tentang pengetahuan batas kecepatan, kecepatan ngebut yang dilakukan dan kondisi yang menyebabkan dia ngebut. Analisa hasil survai lapangan perilaku ngebut dilakukan dengan metode kuantitatif dan analisa persepsi pengemudi dilakukan dengan pendekatan metode kualitatif. Hasil analisa kuantitatif dan kualitatif digunakan untuk menetapkan faktor internal dan eksternal penyebab pengemudi ngebut.

\section{HASIL PENELITIAN}

\section{Karakteristik Responden}

Hasil survey terhadap 300 respondendi Sumatera Barat, diperoleh karakteristik dari responden, karakteristik tersebut ditunjukkan pada Tabel 1.

Tabel 1. Karakteristik responden

\begin{tabular}{|c|c|c|}
\hline No. & Karakteristik & Distribusi \\
\hline 1 & Jenis kelamin & Laki-laki (52.3\%), Perempuan (47.7\%) \\
\hline 2 & Usia & $\begin{array}{l}<17 \text { th }((0.7 \%), 17-20 \text { th }(37.7 \%), 21-25 \text { th }(58 \%), 26-30 \text { th }(1.7 \%), 31-35 \text { th } \\
(0.3 \%), 36-40 \text { th }(0.3 \%), 40-45 \text { th }(0.7 \%),>45 \text { th }(0.7 \%)\end{array}$ \\
\hline 3 & Kota & $\begin{array}{l}\text { Dharmasraya }(0.3 \%) \text {, Solok Selatan }(0.3 \%) \text {, Padang Panjang }(0.3 \%) \text {, Sijunjung } \\
(0.3 \%) \text {, Pasaman }(0.7 \%) \text {, Lima Puluh Kota }(1.7 \%) \text {, Pariaman }(1.7 \%) \text {, Sawahlunto } \\
(1.7 \%) \text {, Pasaman Barat }(2 \%) \text {, Bukittinggi }(2.3 \%) \text {, Padang Pariaman }(2.3 \%) \text {, } \\
\text { Payakumbuh }(2.7 \%) \text {, Solok }(2.7 \%) \text {, Pesisir Selatan }(2.7 \%) \text {, Tanah Datar }(3 \%) \text {, } \\
\text { Agam }(3.7 \%) \text {, Solok }(4.7 \%) \text {, Padang }(67 \%)\end{array}$ \\
\hline 4 & Pendidikan & SMP (1\%), SMA/SMK/MAN (68.3\%), D3 (1\%), S1 (29.3\%), S2 (0.3\%) \\
\hline
\end{tabular}

Tabel 2. Karakteristik mengemudi responden

\begin{tabular}{|c|c|c|}
\hline No. & Karakteristik & Distribusi \\
\hline 5 & Frekuensi mengemudi & $\begin{array}{l}1 \text { minggu sama atau lebih dari } 5 \text { kali }(94.3 \%), 1 \text { minggu kurang } \\
\text { dari } 5 \text { kali }(5.7 \%)\end{array}$ \\
\hline 6 & Pengalaman mengemudi & $\begin{array}{l}<2 \text { th }(3 \%), 2-<5 \text { th }(21 \%), 5-<10 \text { th }(57.3 \%), 10-<15 \text { th }(15.7 \%) \text {, } \\
15-<20 \text { th }(1.7 \%),>20 \text { th }(1 \%)\end{array}$ \\
\hline 7 & $\begin{array}{l}\text { Jenis kendaraan yang sering } \\
\text { digunakan dalam } 6 \text { bln terakhir }\end{array}$ & $\begin{array}{l}\text { Sepeda motor }(87.7 \%) \text {, Mobil (11.2\%), Minibus/Bus }(0.3 \%) \text {, } \\
\text { Sepeda }(0.7 \%)\end{array}$ \\
\hline 8 & $\begin{array}{l}\text { Lama mengemudi rata-rata tiap } \\
\text { hari }\end{array}$ & $\begin{array}{l}<1 \text { jam }(5.3 \%), 1-<2 \text { jam }(28.3 \%), 2-<3 \text { jam }(33 \%), 3-<4 \text { jam } \\
14.3 \%),>4 \text { jam }(19 \%)\end{array}$ \\
\hline 9 & Kepemilikan SIM & Ya $(89.3 \%)$ dan Tidak (10.7\%) \\
\hline
\end{tabular}




\section{Pengetahuan Tentang Batas Kecepatan dan Kecepatan Ngebut Pengemudi}

Perilaku ngebut pengendara sangat dipengaruhi adanya pengetahuan pengendara tentang batas kecepatan mengendarai kendaraan di sebuah wilayah. Untuk mengetahui tingkat pemahaman batas kecepatan dari responden, maka responden diminta menjawab pertanyaaan tentang pengetahuan batas kecepatan dan berapa kecepatan responden mengendarai kendaraan di ruas jalan pada wilayah tersebut, hasil dari wawancara tersebut ditunjukkan pada Gambar 2 hingga Gambar 5.

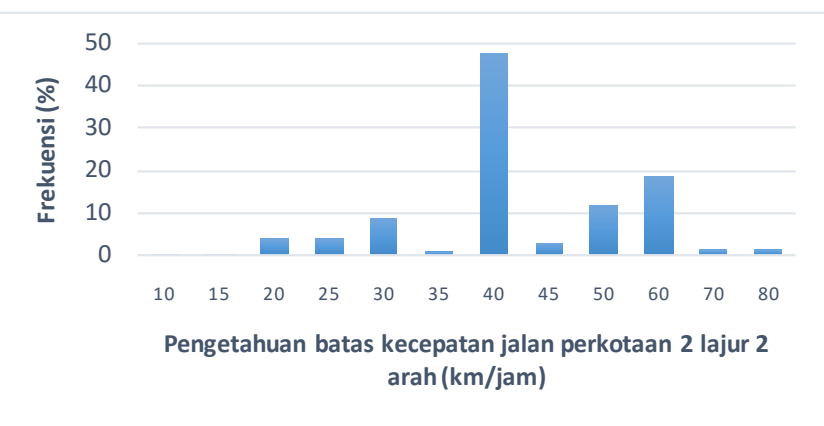

Gambar 2. Pengetahuan responden batas kecepatan jalan perkotaan 2 lajur 2 arah

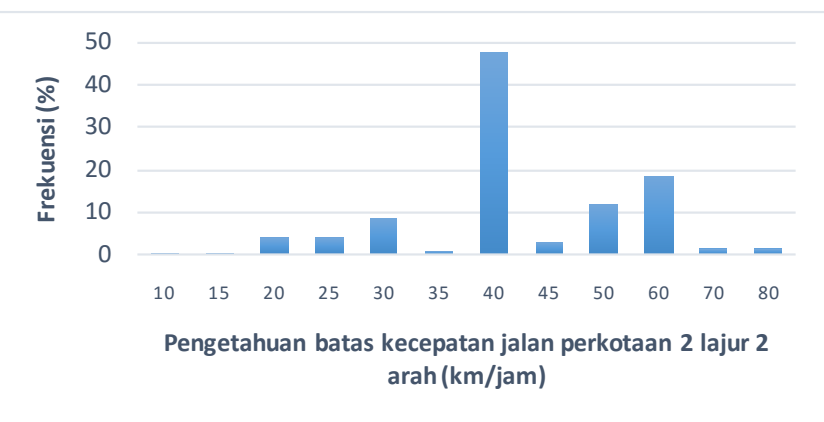

Gambar 4. Pengetahuan responden pada batas kecepatan jalan perkotaan 2 lajur 1 arah

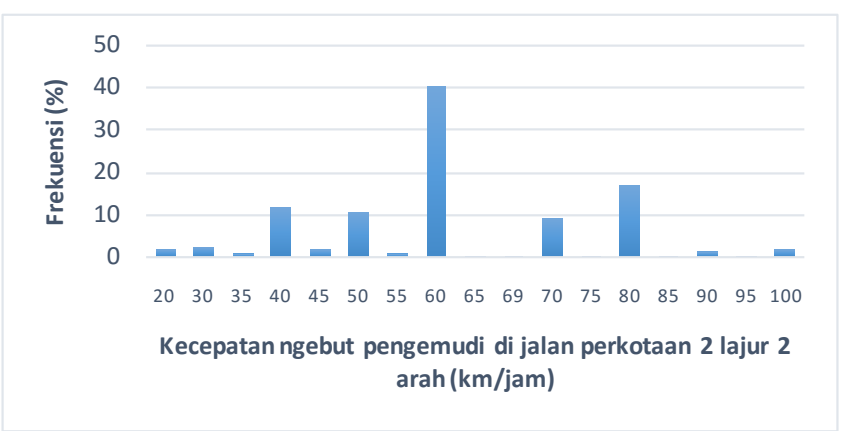

Gambar 3. Kecepatan ngebut responden pada jalan perkotaan 2 lajur 2 arah

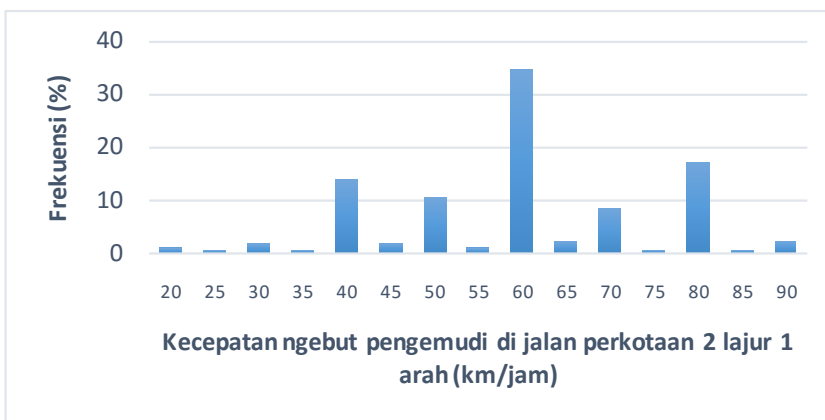

Gambar 5. Kecepatan ngebut responden pada jalan perkotaan 2 lajur 1 arah

Dari Gambar 2 dan 4 menunjukkan hanya $48 \%$ responden yang mengetahui batas kecepatan kendaraan di wilayah perkotaan, pola jawaban responden terhadap pengetahuan batas kecepatan di ruas jalan perkotaan 2 lajur 2 arah dan 2 lajur 1 arah relatif sama. Sedang kecepatan responden pada saat melewati ruas jalan tersebut ditunjukkan pada Gambar 2 dan 4, dari gambar ini ditunjukkan bahwa lebih dari $15 \%$ responden yang ngebut di ruas jalan tersebut melebihi batas kecepatan yang ditetapkan. Dari kurva pada Gambar 2 -5 , terdapat persentase jumlah responden ngebut yang lebih besar dibandingkan dengan responden yang tidak mengetahui batas kecepatan, hal ini sangat mungkin disebabkan alasan lain sehingga responden harus ngebut.

\section{Persepsi Pengemudi Ngebut di Jalan}

Pada saat ngebut, pengemudi kendaraan pada umumnya melakukan tindakan tersebut didasarkan atas persepsi tertentu, Gambar 5 - 10 ini merupakan beberapa persepsi yang menjadikan mayoritas responden mengendarai kendaraan dengan ngebut. 


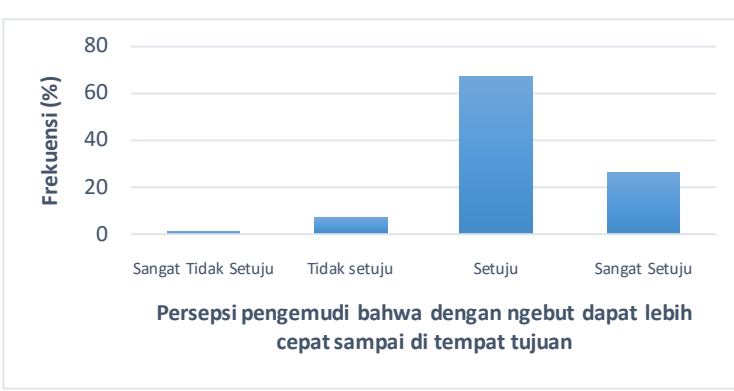

Gambar 6 Persepsi pengemudi tentang ngebut dapat lebih cepat sampai di tempat tujuan

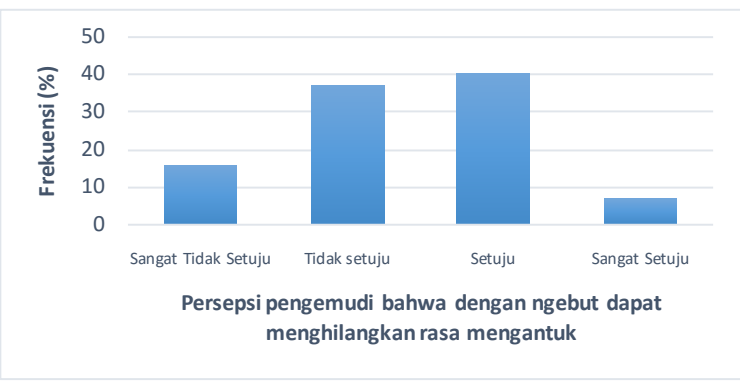

Gambar 8. Persepsi pengemudi tentang ngebut dapat menghilangkan rasa mengantuk

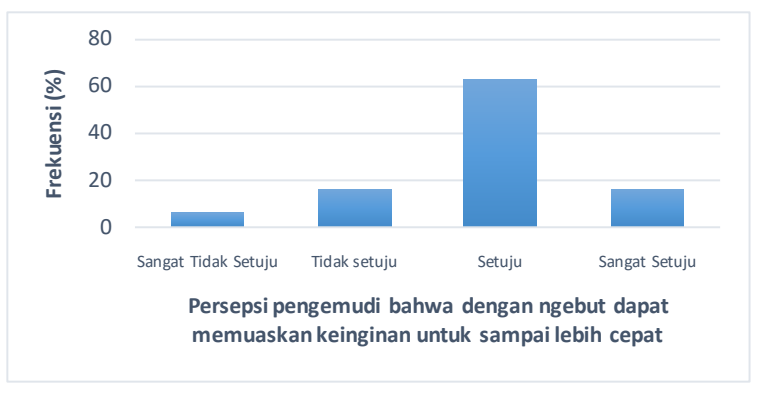

Gambar 10. Persepsi pengemudi tentang ngebut dapat memuaskan keinginan untuk sampai lebih cepat

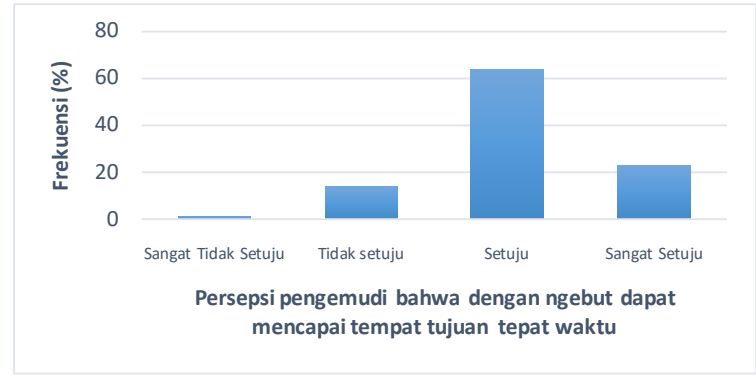

Gambar 7. Persepsi pengemudi tentang ngebut dapat mencapai tempat tujuan tepat waktu

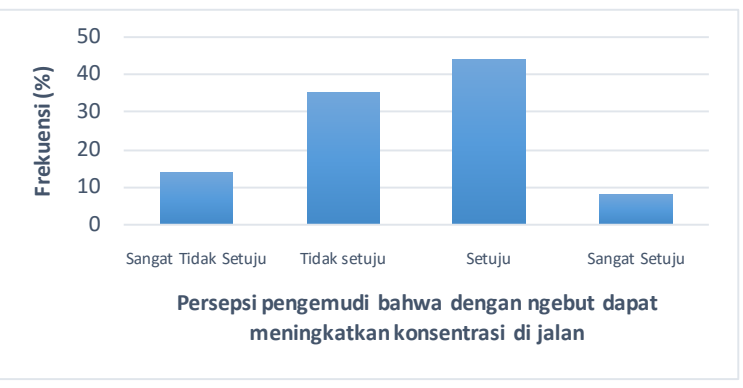

Gambar 9. Persepsi pengemudi tentang ngebut dapat meningkatkan konsentrasi di jalan

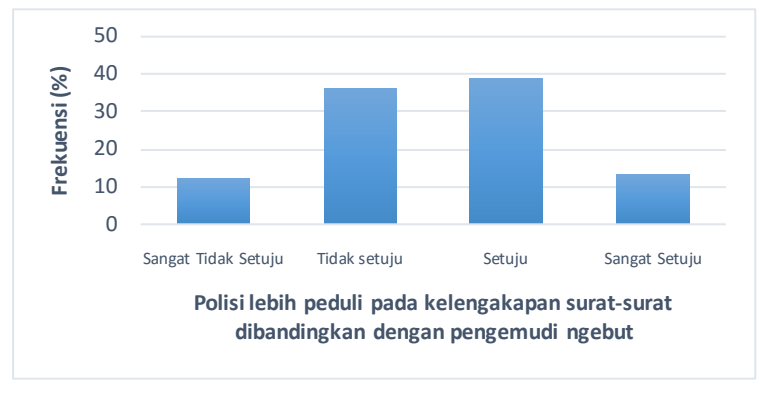

Gambar 11. Persepsi pengemudi tentang ngebut bahwa polisi lebih peduli pada kelengkapan surat dibandingkan ngebut

Gambar 6 hingga Gambar 11 menunjukkan bahwa, keinginan mayoritas responden untuk cepat sampai tujuan dengan tepat waktu merupakan faktor yang umumnya menjadi alasan responden mengendarai kendaraan dengan ngebut. Selain faktor tersebut, mayoritas responden mengendarai kendaraan dengan ngebut untuk menghilangkan rasa ngantuk, meningkatkan kosentrasi di jalan, dapat memuaskan keinginan untuk sampai lebih cepat dan karena polisi lebih peduli pada kelengkapan surat kendaraan dibandingkan dengan tindakan ngebut.

\section{Perilaku Ngebut Pada Jam Puncak dan Tidak Puncak}

Untuk mengetahui perilaku ngebut di jalan, selain dilakukan survai secara online, namun juga dilakukan survai kecepatan setempat (spot speed) di ruas jalan Adinegoro. Survai dilakukan pada jam puncak dan jam tidak puncak untuk melihat persentase jumlah pengemudi yang ngebut pada kondisi lalu lintas yang berbeda. Hasil analisa data survai ditunjukkan pada Gambar 12 hingga Gambar 21. 


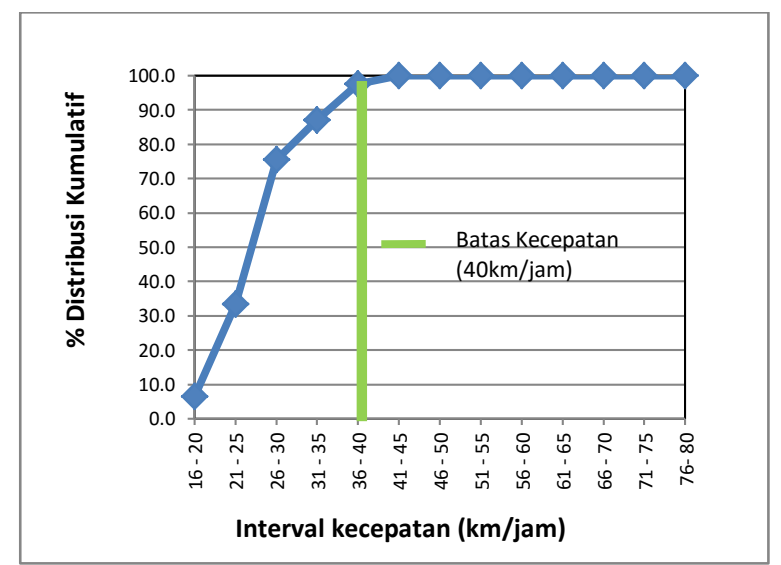

Gambar 12. Frekuensi kumulatif spot speed jam puncak pagi (6.30-7.30) arah Padang-Bukittinggi

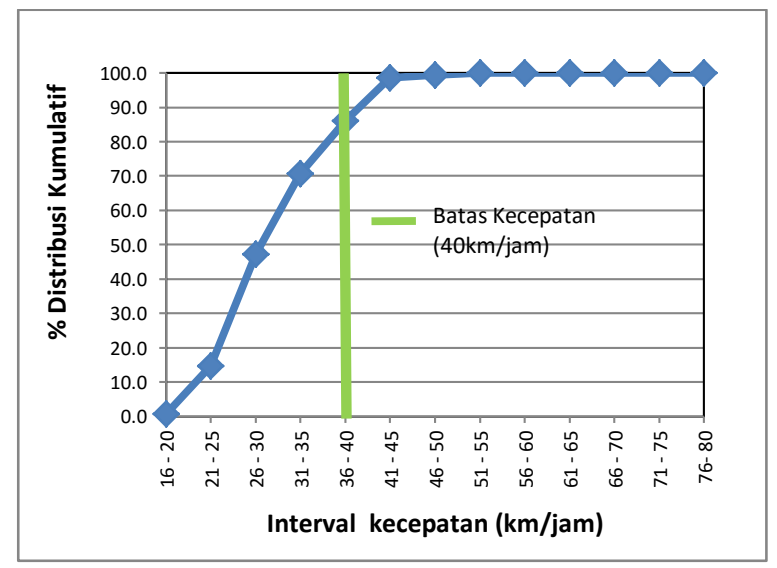

Gambar 14. Frekuensi kumulatif spot speed jam tidak puncak pagi (9.00-10.30) arah Padang-Bukittinggi

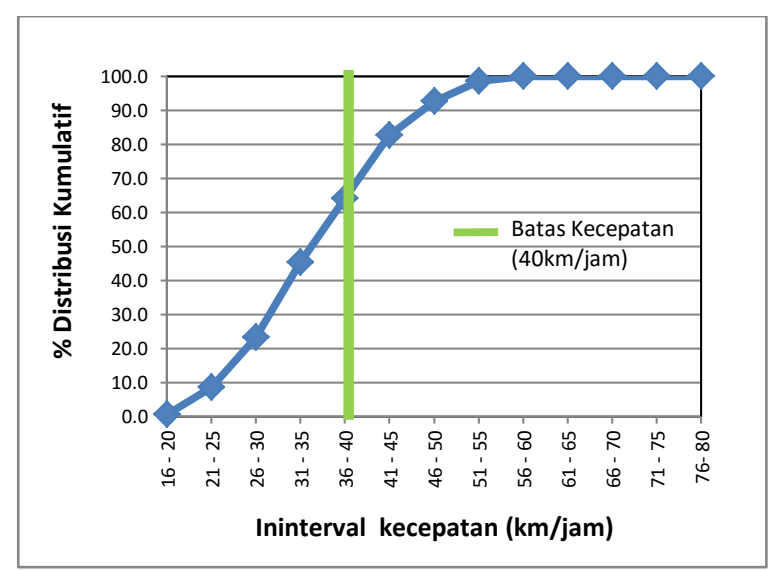

Gambar 16. Frekuensi kumulatif spot speed jam tidak puncak siang (14.15-15.15) arah Padang-Bukittinggi

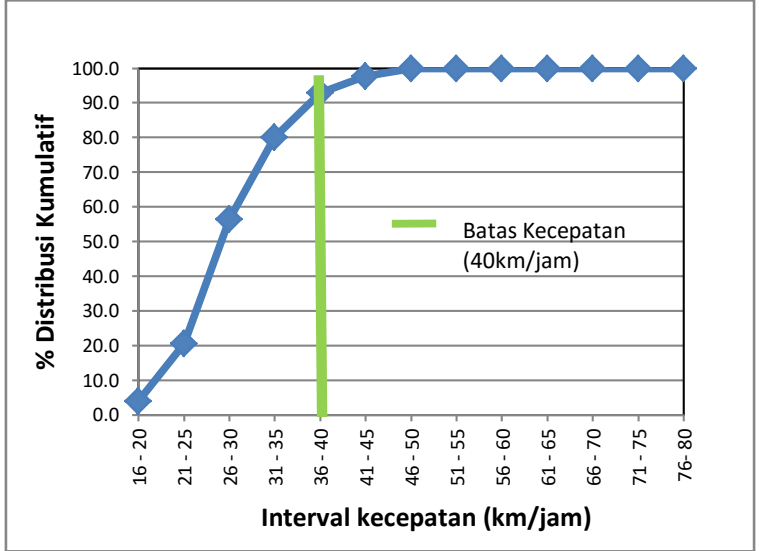

Gambar 13. Frekuensi kumulatif spot speed jam puncak pagi (6.30-7.30) arah

Bukittinggi-Padang

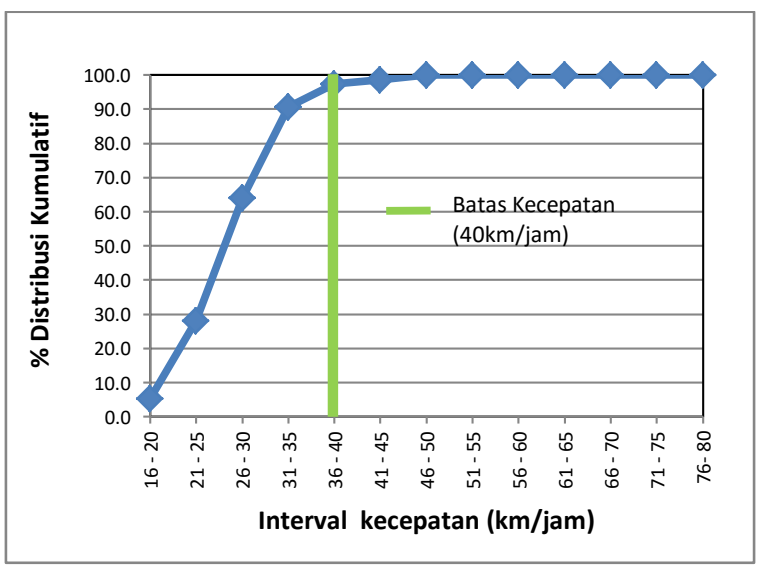

Gambar 15. Frekuensi kumulatif spot speed jam tidak puncak pagi (9.00-10.30) arah Bukittinggi-Padang

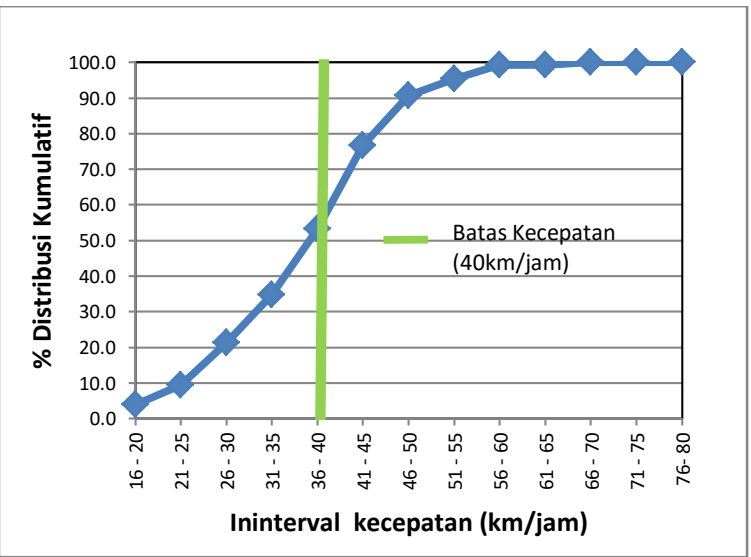

Gambar 17. Frekuensi kumulatif spot speed jam tidak puncak siang (14.15-15.15) arah Bukittinggi-Padang 


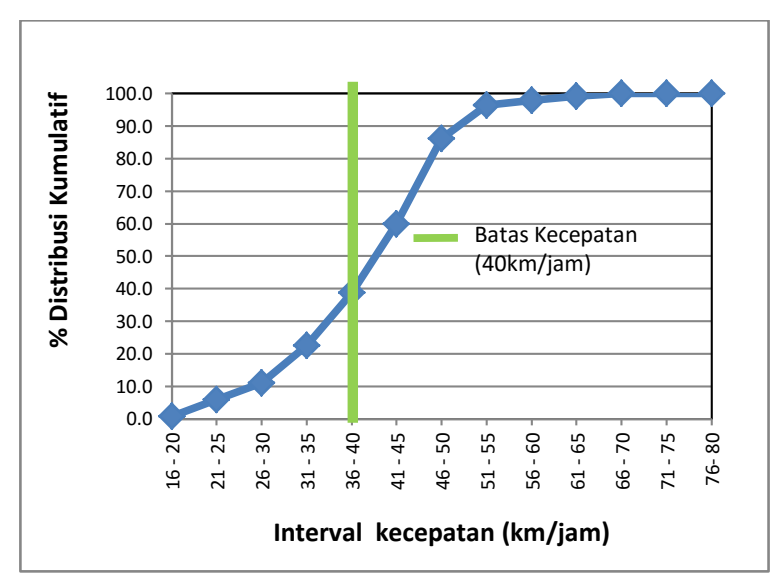

Gambar 18. Frekuensi kumulatif spot speed jam puncak sore (17.00-18.00) arah Padang-

Bukittinggi

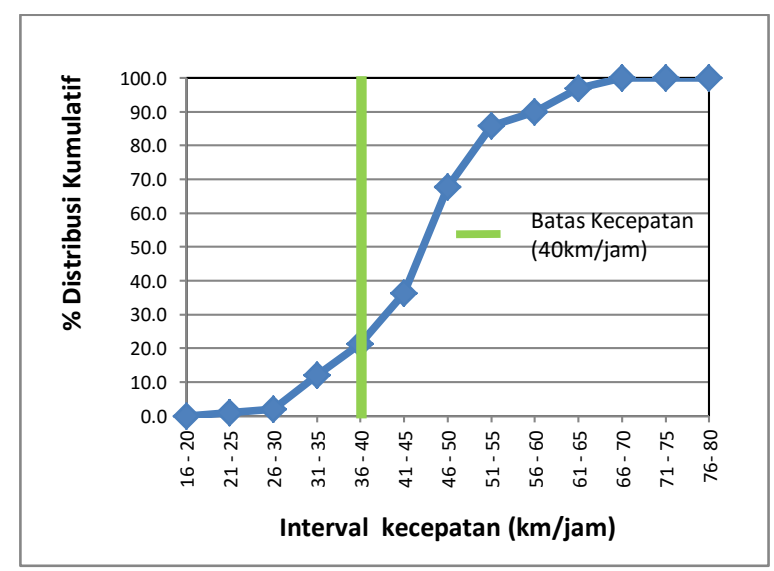

Gambar 20. Frekuensi kumulatif spot speed jam tidak puncak malam (20.00-21.00) arah PadangBukittinggi

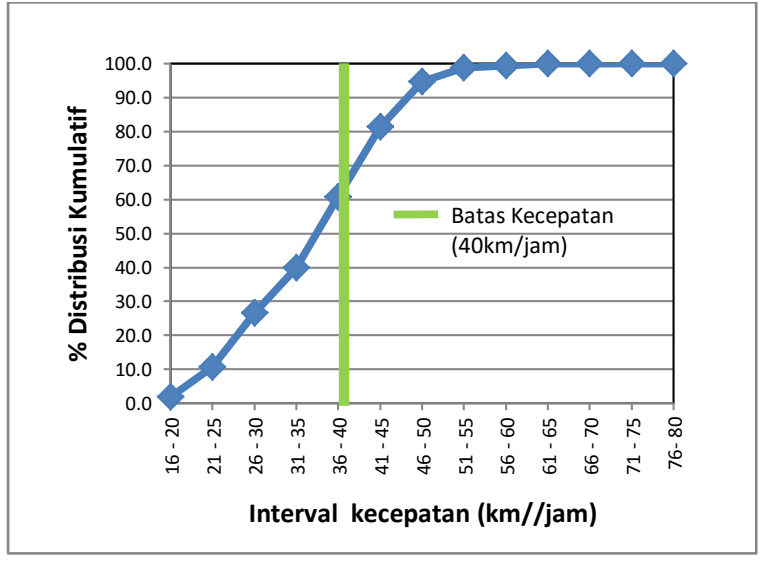

Gambar 19. Frekuensi kumulatif spot speed jam puncak sore (17.00-18.00) arah Bukittinggi-

Padang

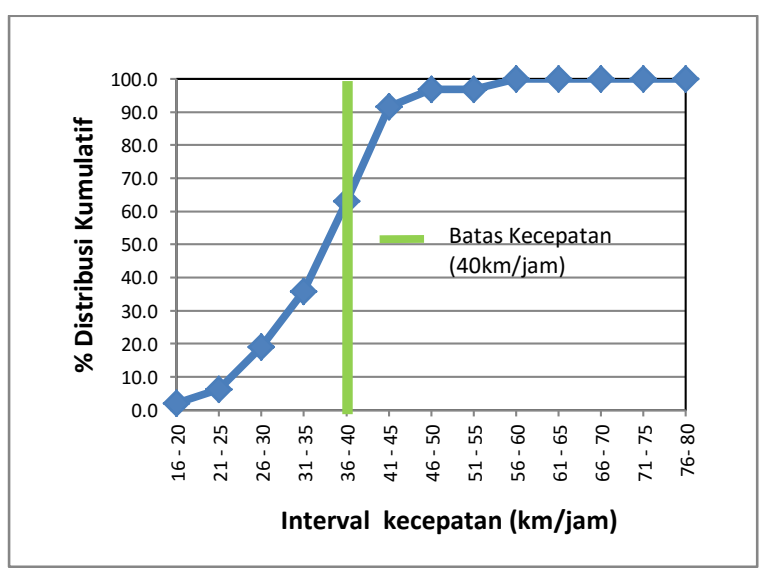

Gambar 21. Frekuensi kumulatif spot speed jam tidak puncak malam (20.00-21.00) arah

Bukittinggi-Padang

Dari Gambar 12-21 ditunjukkan pengendara yang ngebut dengan kecepatan diatas batas yang ditetapkan $(40 \mathrm{~km} / \mathrm{jam})$, pada saat jam puncak pagi hari persentase kecepatan ngebut yang lebih besar dari $40 \mathrm{~km} / \mathrm{jam}$ relatif rendah, hal ini disebabkan karena volume lalu lintas pada saat itu relatif tinggi sehingga pergerakan kendaraan untuk ngebut menjadi terbatas. Persentase pengendara yang ngebut meningkat pada saat sore dan malam hari, persentase tertinggi pengendara ngebut terjadi saat jam $20.00-21.00$, terdapat $80 \%$ pengendara ngebut diatas $40 \mathrm{~km} / \mathrm{jam}$ untuk arah Padang - Bukittinggi dan $63 \%$ untuk arah Bukittinggi - Padang. Pada jam 17.00-18.00 terdapat persentase pengendara yang ngebut cukup tinggi (62\% arah Padang - Bukittinggi dan $40 \%$ arah Bukittinggi - Padang), padahal saat itu adalah jam puncak sore hari, dari analisa data volume lalu lintas jam puncak pada saat itu berkisar antara 700 kendaraan/jam/lajur, dengan volume lalu lintas pengendara masih mampu mengendarai kendaraan dengan kecepatan tinggi.

Dari hasil analisa persepsi pengemudi tentang ngebut, dan membandingkan hasilnya dengan data kecepatan hasil dari survai di lapangan, terdapat pola yang menguatkan kebenaran atas persepsi pengemdi yang ngebut tersebut. Pengemudi sebagian besar tidak mengetahui batas kecepatan berkendara, dan mereke ngebut karena ingin cepat sampai 
tujuan, sedang pada saat ini polisi tidak melakukan penindakan pada pengemudi yang ngebut.

\section{KESIMPULAN}

Dari hasil penelitian ini dapat disimpulkan bahwa perilaku ngebut dari pengemudi dipicu oleh faktor internal dan eksternal yang ada. Faktor internal yang menjadi penyebab pengemudi ngebut adalah ketidaktahuan batas kecepatan mengemudi di wilayah perkotaan, faktor internal lain yang mempengaruhinya adalah adanya keinginan pengendara untuk cepat sampai di tujuan dengan tepat waktu. Sedang faktor eksternal yang mempengaruhinya adalah kondisi lalu lintas yang ada memungkinkan pengendara untuk ngebut, selain hal itu, tidak dikenakannya sanksi kepada pengemudi yang ngebut sehingga mereka mengendarai kendaraan dengan ngebut. Dari hasil analisa data hasil survai, pengendara ngebut tidak hanya pada jam tidak sibuk, namun mereka juga ngebut pada jam sibuk, hal ini mereka lakukan karena kondisi lalu lintas yang ada memungkinkan dilakukannya ngebut. Persentase pengemudi ngebut meningkat pada saat sore dan malam hari, hal ini disebabkan karena volume lalu lintas yang rendah.

\section{UCAPAN TERIMA KASIH}

Ucapan terima kasih disampaikan kepada Korlantas yang telah membiayai penelitian ini, tim asisten laboratorium Jalan Raya dan Transportasi yang telah membantu dalam pelaksanaan survai lalu lintas.

\section{DAFTAR PUSTAKA}

Corner, M., Lawton, R., Parker, D., Chorlton, K., Manstead, A, S, R., and Stradling, S., (2007), Application of the theory of planned behavior to the prediction of objectively assessed breaking of posted speed limits, British Journal of Psychology, Vol.99, pp429-453.

Haustein, S and Maller, M., (2014), Peer Influence on Speeding Behaviour Among Male Drivers Ages 18 and 28, Accident Analysis and Prevention, Vol.64, pp92-99.

Jusuf, A., Nurprasetio, I, P., Prihutama, A, (2017), Macro Data Analysis of Traffic Accidents in Indonesia, Journal of Engineering and Technological Sciences Vo.49 No.1 2017, pp132-143

Korlantas, (2019), Jenis Cedera Untuk Kelompok Umur Korban, http://korlantasirsms.info/graph/ (diakses 25 Juli 2019

Mehmood, A. (2007). Understanding the Dynamic of Causal Factors Related to Excessive Speeding Behaviour of the Drivers, Proceeding of The 2007 International Conference of the System Dynamics Society, July 29 - August 2, 2007, Boston. https://www.systemdynamics.org/assets/conferences/2007/proceed/index.htm (diakses 29 Juli 2019)

Soehodho, S, (2009), Road Accidents in Indonesia, IATSS Research Vol. 33 No.2 2009 pp122-124

Santosa, S., P, (2017), Anatomy of Injury Severity and Fatality in Indonesian Traffic Accidents, Journal of Engineering and Technological Sciences Vo.49 No.3 2017, pp412-422 
Warner, H, W., (2006), Factors Influencing Drivers' Speeding Behaviour, PhD Dissertation, ACTA Universitatis Upsaliensis Uppsala. https://www.diva-portal.org/smash/get/ (diakses 29 Juli 2019) 